\title{
9
}

\section{Aftermath: The Dissembling Publisher, Quadrant and the History Wars}

The public debate over Australian history has been conducted for the most part in terms of truth and falsehood. While the motives and integrity of participants are part of that debate, there is surprisingly little attention to the ethical dimensions of historical scholarship. If it is a fundamental duty of the historian to tell the truth, then that hardly exhausts the obligations that arise when we work with the past. The choice of subject, the engagement with the sources, respect for the evidence, fair dealing with the work of others, attention to context, humility in the exercise of judgement and recognition of what cannot be known-these are just some of the responsibilities a researcher incurs. The mediation between past and present is a profoundly moral activity. Of all the faculties of the historian, a good conscience is indispensable. Technical virtuosity will disguise many faults, but not bad faith.

Stuart Macintyre $(2004)^{1}$

Quadrant maintained its onslaught against Manning Clark-to the extent that, when launching Mark McKenna's An Eye for Eternity in 2011, novelist Tom Keneally cheekily remarked on the number of friends of Clark in attendance and the 'under-representation from Quadrant, who

1 Stuart Macintyre, 'Introduction' to Macintyre (ed.), The Historian's Conscience: Australian Historians on the Ethics of History, Melbourne: MUP, 2004, pp. 1-16, specifically pp. 4-5. 
take such a passionate interest in his work'. ${ }^{2}$ Since 1994, the journal has published numerous articles, in addition to those by Peter Ryan, dealing wholly or partly with Clark (see Appendix 4). Some constitute fair comment, but the majority are one-sidedly hostile. It seems that many of the History Warriors thought they were settling something important about understandings of the national past by continuing to debase Clark's character.

Quadrant had given Ryan a new lease of journalistic life and an audience, although not nearly as good as a column in a major metropolitan daily given that he now lacked a broadly based readership and was preaching to the converted. He had a roving commission to write about whatever he liked, and he often did so with tacky commentary and cruel invective. There was no doubting his likes and dislikes as he roamed freely, sometimes reviewing a book but mostly engaging in wider commentary. Military history, educational issues and Papua New Guinea were frequently on the menu, as were a long list of pet hates-including the chattering classes, organised sport (i.e. team games), animal libbers, the peace movement, school teachers, tree-huggers (although he didn't use that term) and other environmentalists, the notion of the Stolen Generation, republicanism, academics generally, beards, feminists, exposed belly-buttons and pierced navels. ${ }^{3}$ Such commentary led Geoffrey Serle to record the 'distress' of Ryan's old friends that the person who once 'burned with radical idealism' had transformed into 'a standard elderly, misanthropic newspaper columnist'. ${ }^{4}$

From his pulpit, he could smite his enemies and praise his friends, as well as pronounce on the decaying state of the nation. Such interventions, when he went into attack mode, could be venomous. Mirroring his Age columns, his tactics were disparagement, insult, ridicule and put-downs. Take the opening sentences of his first Age column for 1993:

One of the happier notes struck during this festive season was inaudible: The Australian republican movement was silent, like Sherlock Holmes's dog that did not bark at night. No theatricality

2 Tom Keneally, at the launch of An Eye for Eternity, Sydney, 19 May 2011 (starting at 4.44 minutes), available on 28 November 2011 at: www.mup.com.au/page/92 (no longer available on the MUP website).

3 A selection of his Quadrant articles is in Peter Ryan, It Strikes Me: Collected Essays, 1994-2010, Sydney: Quadrant Books, 2011.

4 Geoffrey Serle, Robin Boyd: A Life, Melbourne: MUP, 1995, p. 103; see also Paul Bourke 'Ryan is playing with the "pornography of power", Canberra Times, 28 August 1993, p. 4. 
from those old self-promoters Tom Keneally and Donald Horne; Patrick White and Manning Clark are quiet forever; Paul Keating pondered the resurrection of John ('Lazarus') Hewson. All in all a good Christmas. ${ }^{5}$

Further down the column he writes:

Consider: among our prime ministers we have endured drunks, hysterics, barnyard roosters, gays, near-cretins, sires of illegitimate children and persons with fingers so sticky that you oughtn't to let them near the fowlhouse, let alone the Treasury.

Not without reason did an acquaintance from their University of Melbourne days describe Ryan's Age columns as having 'a certain idiosyncratic, sometimes amusing, point of view, but always very negative ... and sometimes quite grotesque, full of bitterness and selfrighteousness' ${ }^{6}$

As well, Ryan became a regular reviewer for the Australian, which gave him added scope for sledging the historical profession. ${ }^{7}$ He continued writing for Quadrant until shortly before his death in late 2015. His last two columns are thoroughly unpleasant personal attacks on the historian Brian Fitzpatrick. ${ }^{8}$

But what inspired Ryan to write with such bitterness and ill-feeling? A possible answer is that he was psychologically scarred during wartime service in the New Guinea campaign; he certainly went through terrifying ordeals in that perilous theatre of war. Service records are often detailed but Ryan's is thin and it neither confirms nor denies torments that would

5 Peter Ryan, 'Constitution is not the problem', Age, 2 January 1993, p. Extra 2.

6 Bruce Anderson to Dymphna Clark, 28 August 1993, Dymphna Clark Papers, NLA, MS 9873, Series 10, Box 35, Folder 2.

7 For example, Peter Ryan, 'All hail the unlikely saviour', review of The Fabrication of Aboriginal History, by Keith Windschuttle, Australian, 10 January 2003, p. 11 (where he rails against Windschuttle's opponents in the academy); Ryan, 'Tyranny of the trivia', review of The Fuss That Never Ended: The Life and Work of Geoffrey Blainey, ed. Deborah Gare, Geoffrey Bolton, Stuart Macintyre and Tom Stannage, Weekend Australian, 15-16 March 2003, p. 10; Ryan, 'Fighting words', review of The History Wars, by Macintyre and Clark, Australian, 6-7 September 2003, pp. R10-11.

8 Peter Ryan, 'The Unforgotten Brian Fitzpatrick', Quadrant, vol. 59, no. 9, September 2015, pp. 111-12; Ryan, 'In the Neighbourhood of Brian Fitzpatrick', Quadrant, vol. 59, no. 10, October 2015, pp. 110-12. He was still managing to make factual errors. At the time of her marriage in 1932, Kathleen Fitzpatrick was not 'soon to be Professor of History at [the University of] Melbourne', as Ryan stated in 'The Unforgotten Brian Fitzpatrick', p. 111. She was eventually promoted to associate professor 16 years later, in 1948, and she declined to be considered to fill the newly created second chair of history within the department in 1955. 
have had lasting effects on his mental state. He contracted malaria in late 1943 and suffered lifelong recurrences, but in November 1945 his medical classification was 'A1'. ' During his time in the University of Melbourne Labour Club in the late 1940s, pugnacity was the dominant characteristic, ${ }^{10}$ but was this a function of his wartime experiences? Given the paucity of information in Ryan's service file, it is impossible to say whether his capacity for unpleasantness was pre-existing or related to his war service. All the same, it is hard not to wonder whether all the pieces were working together properly. There is more than just eccentricity or crankiness in motion.

Yet Ryan was more than capable of writing in a constructive vein, providing there was no axe to grind. But this was not in evidence when he turned his gaze to Clark, contributing to Quadrant's continued denigration of the deceased historian (Appendix 3). The majority of Ryan's 19 articles simply deliver a passing swipe-for example:

Serious history had vanished under the fog of Manning Clark's fantasies, until our national story virtually ceased either to be taught or to be learned; Australia’s strong and self-respecting sense of self was evaporating. ${ }^{11}$

In several instances he revisits the 1993 affair, defending his position and repeating his attacks on Clark. Here, he reverts to type in saying that his politely expressed views exposing 'the hollowness of Manning Clark drew abuse, but did not draw even an attempt to answer any of the clear questions I had asked'. ${ }^{12}$ In fact, he didn't ask any 'clear questions' and he said nothing new about the History despite claiming to have read all six volumes 'not merely once throughout, but three times, and some parts

9 Ryan's Service file, NAA: B883, VX128541 (pp. 24-25, 35).

10 Stuart Macintyre, email to author, 22 August 2019 (based on Macintyre's research in the Records of the Labour Club).

11 Peter Ryan, 'A Better Place', Quadrant, vol. 47, nos 1-2, January-February 2003, pp. 119-20, specifically p. 119.

12 Peter Ryan, 'A Reply to my Critics', in his Lines of Fire: Manning Clark \& Other Writings, ed. A.K. Macdougall, Binalong, NSW: Clarion Editions, 1997, pp. 214-22, specifically p. 217; Ryan to J.P. Parsons, 16 December 1993, Ryan Papers, National Library of Australia (hereafter NLA), MS 9897, Series 6, Box 10, Folder 5; Ryan, 'Kokoda in Perspective', Quadrant, vol. 50, no. 6, June 2006, pp. 95-96, for quotation see p. 96; Ryan, 'Manning Clark's second coming', Australian, 10 February 2007, p. 29; Ryan,'Hollow Man of Yesterday', review of Manning Clark: A Life, by Brian Matthews, Quadrant, vol. 53, nos 1-2, January-February 2009, pp. 126-27; Ryan, 'My Life as a Leper', Quadrant, vol. 55, nos 1-2, January-February 2011, pp. 127-28; Ryan, 'The Only Justifiable End of Eloquence', Quadrant, vol. 57, no. 9, September 2013, pp. 111-12, specifically p. 111. 
oftener'. ${ }^{13}$ That he was unable to come up with ideas of his own in his critique of Clark the historian led Frank Bongiorno to question Ryan's intellectual capacities:

He might have had literary skills but I'm not aware of any work of genuine insight or originality by Ryan. He seems a shallow thinker, capable of clever literary allusion but without any interest in sustained research or difficult analysis. ${ }^{14}$

Indeed, presenting new factual details to illustrate wider issues that others had rehearsed many times over is not the same thing as originality or profundity.

Ryan's often denunciatory and combative column is a microcosm of Quadrant's worsening habits of ideological aggression and personal abuse. Some of this can be put down to Quadrant always having seen itself as anti-communist and oppositional to the left-leaning journals such as Meanjin and Overland. ${ }^{15}$ Quadrant had also reinvented itself in the late 1980s; now seeing itself as a bastion against the new ideologies — 'radical feminism, gay liberationism, anti-nuclearism, extreme environmentalism, multi-culturalism, animal liberationism'-which it perceived as having replaced communism as the major threats to cultural freedom. ${ }^{16}$ Just as Clark's History generally deteriorated with successive volumes, Quadrant has not improved with age, although it does from time to time publish articles contrary to its own party line. ${ }^{17}$ Its second editor, Peter Coleman (1967-1988), was a courteous enough conservative, although he moved further to the right as the History Wars progressed. Robert Manne, who took over the editorship in 1990, had no intention of turning

13 Peter Ryan, 'Manning Clark', in his Lines of Fire, pp. 179-214, specifically p. 213.

14 Frank Bongiorno, comment on earlier version of this book, 29 July 2018.

15 James McAuley, 'The First 15 Years', Quadrant, vol. 15, no. 10, October 1971, pp. 13-16; Jim George and Michael Hutchinson, 'Culture War as Foreign Policy in the US and Australia', in Jim George and Kim Huynh (eds), The Culture Wars: Australian and American Politics in the 21st Century, Melbourne: Palgrave Macmillan Australia, 2009, pp. 37-56, specifically pp. 47-52; Norman Abjorensen, 'The Culture Wars Down Under', in Jim George and Kim Huynh (eds), The Culture Wars: Australian and American Politics in the 21st Century, Melbourne: Palgrave Macmillan Australia, 2009, pp. 59-74, specifically p. 62; Phillip Edmonds, Tilting at Windmills: The Literary Magazine in Australia, 1968-2012, Adelaide: University of Adelaide Press, 2015, pp. 149-52, doi.org/10.20851/ windmills; and, more generally, David Carter and Roger Osborne, 'Periodicals', in Robyn SheahanBright and Craig Munro (eds), Paper Empires: A History of the Book in Australia, 1946-2005, Brisbane: University of Queensland Press, 2006, pp. 239-57.

16 'Editorial: A Short Way with Dissenters', Quadrant, vol. 33, no. 3, March 1989, p. 7.

17 For example, S.G. Foster, 'Contra Windschuttle', Quadrant, vol. 47, no. 3, March 2003, pp. 25-28. A measured assessment of Quadrant is by Don Aitkin, 'Why Do I Read Quadrant', Australian Quarterly, vol. 79, no. 1, 2007, pp. 9-16. 
Quadrant into 'an Australian Thatcherite magazine, socially conservative and economically dry'. Manne did give the journal renewed intellectual substance but his relations with Quadrant colleagues became increasingly fraught. His critique of economic rationalism and neoliberal policy in 1992 resulted in the first major rupture. ${ }^{18}$ His espousal of Aboriginal concerns, which included articles on Mabo by Raimond Gaita, caused further consternation, as did his refusal to buy into the spy-of-the-century nonsense played out in the Courier-Mail in which Quadrant's literary editor, poet Les Murray (1938-2019), alleged he had seen Manning Clark wearing the Order of Lenin. ${ }^{19}$ The parting of the ways came in 1997 because his accumulated differences with the editorial board had become insurmountable. ${ }^{20}$ Even then Clark was in the mix because Manne's refusal to publish a submission by Hal G.P. Colebatch, which fingered Clark as an anti-Semite, helped to catalyse the revolt. ${ }^{21}$ Symbolic of the advent of a new order at Quadrant was the publication of an article, in opposition to Manne's views, supporting the allegations of the Brisbane Courier-Mail that Clark was the recipient of the Order of Lenin and an agent of Soviet influence. ${ }^{22}$ The parting of the ways was acrimonious and Manne has since had to field repeated brickbats from the journal he once edited, not least from Peter Coleman who was very bitter about Manne's 'virtuous trajectory' and where this had taken the journal. ${ }^{23}$

18 John Carroll and Robert Manne (eds), Shutdown: The Failure of Economic Rationalism and How to Rescue Australia, Melbourne: Text Publishing, 1992.

19 Robert Manne, 'On the Manning Clark Affair' (1996), in his Left Right Left: Political Essays, 1977-2005, Melbourne: Black Inc., 2004, pp. 81-91; Peter F. Alexander, Les Murray: A Life in Progress, Melbourne: Oxford University Press, 2000, pp. 276-78; Raimond Gaita, 'Mabo (Part One)', Quadrant, vol. 37, no. 9, September 1993, pp. 36-39; Gaita, 'Mabo (Part Two), Quadrant, vol. 37, no. 10, October 1993, pp. 44-48. In the interest of open discussion, Manne published a retort to Gaita-namely Ron Brunton, 'Shame about Aborigines', Quadrant, vol. 41, no. 5, May 1997, pp. 36-39.

20 Robert Manne, 'Why I have Resigned', Quadrant, vol. 41, no. 12, December 1997, pp. 3-4. Cf. Frank Devine, 'Welcome changing of the guard for a journal of debate', Australian, 5 January 1998, p. 11. 21 Andrew Bonnell and Martin Crotty, 'Australia’s History under Howard, 1996-2007', pp. 15657, Annals of the American Academy of Politics and Social Science, vol 617, no. 1, 2008, pp. 149-65, doi.org/10.1177/0002716207310818; Stuart Macintyre and Anna Clark, The History Wars, 2nd edn, Melbourne: MUP, 2004, pp. 145-46; Alexander, Les Murray, p. 283. Quadrant later published Colebatch's 'Manning Clark's Anti-Semitism', Quadrant, vol. 52, no. 5, May 2008, pp. 92-97. Colebatch (1945-2019) was a journalist, university lecturer and historian of reactionary persuasion whose broadsides against Manning Clark verged on the paranoid.

22 Wayne Smith, 'Manning Clark and the Courier Mail', Quadrant, vol. 42, no. 9, September 1998, pp. 40-43. Cf. Robert Manne, 'Christ and Lenin', The Australian's Review of Books, October 1996, pp. 6-8.

23 For example, Peter Coleman, 'All that Swagger: Robert Manne's Virtuous Trajectory', review of Left Right Left: Political Essays, 1977-2005, by Robert Manne, Quadrant, vol. 49, no. 9, September 2005, pp. 82-84, available at: www.the-rathouse.com/PC_Manne.html; Keith Windschuttle, 'A Cribber and a Fibber', Quadrant, vol. 52, no. 5, May 2008, pp. 98-103; and numerous more recent swipes on the Quadrant webpage, available at: quadrant.org.au/. 
Beyond his Quadrant column, Ryan's obsession with Clark was demonstrated when approached by researchers. During an interview in 2007, McKenna observed that 'talking about Clark seemed to animate [Ryan's] whole being. ${ }^{24}$ Much the same emerged when Sylvia Martin interviewed Ryan for her biography of Ida Leeson. In his second volume of autobiography, Clark told the blatantly sexist story that he and other young researchers had a daily competition at the Mitchell Library: they would request books on the high shelves and the prize would go to the first to identify the colour of the garters under Leeson's skirts as she ascended the ladder. That Ryan kept repeating the story during the interview is further evidence of his obsession with Clark. Ryan then spent one-third of his review of the Leeson biography on the garters scenario. He ended by saying that her book was not 'enhanced' by relating such information despite Martin concluding that the story was probably apocryphal..$^{25}$ This is not to excuse Clark, any more than the occasion in the late 1940s when he described his departmental colleague Kathleen Fitzpatrick to Ryan as 'the Unsatisfied One'-a tasteless remark about a divorcée who had not remarried and in fact never did. Ryan 'said he was appalled by the comment when Clark made it, and was still appalled by it now', but there is no evidence of any remonstrance from Ryan at the time. ${ }^{26}$

Ryan continued to chisel away at the reputation of Manning Clark, but, on a broader front, one senses an ambiguity in conservative circles in dealing with Clark's legacy and reputation. The reaction alternated between denunciation and cold-shouldering, which happened at Quadrant's fiftieth anniversary celebrations in 2006. One of the speakers was John Howard, who denounced Clark as an example of 'the philo-communism that was once quite common in Australia in the 1950s and 1960s'. ${ }^{27}$ He was evidently unaware that Clark had been actively recruited on to Quadrant's foundation editorial board, and equally oblivious to the fact that Clark

24 Mark McKenna, An Eye for Eternity: The Life of Manning Clark, Melbourne: Miegunyah Press, 2011 , p. 690.

25 Sylvia Martin, Ida Leeson: A Life: Not a Blue-stocking Woman, Sydney: Allen \& Unwin, 2006, pp. 187-88 (and email to author, 4 July 2016); Manning Clark, The Quest for Grace, Ringwood: Penguin Books, 1991, pp. 167-68; Ryan, 'Woman of letters', review of Ida Leeson, by Sylvia Martin, Weekend Australian Review, 15-16 July 2006, pp. 14-15.

26 Elizabeth Kleinmetz, A Brimming Cup: The Life of Kathleen Fitzpatrick, Melbourne: MUP, 2013, pp. 156, 292 n.63.

27 John Howard, 'A Tribute to Quadrant', Quadrant, vol. 50, no. 11, November 2006, pp. 22-24, specifically p. 22. 
had long since expressed his dismay at 'the intransigence and the bullying of the Soviets' ${ }^{28}$ Peter Coleman also spoke that evening and he certainly knew about Clark's early association with Quadrant, having helped to coopt him onto the original editorial board, but he left Clark out of his address altogether. ${ }^{29}$

Clark's critics were handed ammunition when it was revealed, in 2007, that Clark had not been in Germany at the time of Kristallnacht in late 1938, as he had repeatedly claimed, when Nazi storm troopers went on their state-sanctioned rampage against Jewish persons and property. He actually arrived in Germany a fortnight later, but in subsequent years he appropriated the account in Dymphna's letters and made their content his own, claiming that what he witnessed the night after Kristallnacht was an epiphany. ${ }^{30}$ Discovery of the subterfuge caused a brief flurry—nothing of the magnitude of the Courier-Mail episode-with assertions that Clark was indeed a fraud, as he was on that occasion. ${ }^{31}$

There was, however, a countervailing unease in right-wing circles that exposés of Clark perpetuated the unworthy legacy of someone best forgotten-the feeling that the ghost of Manning Clark be allowed to slink back to the obscurity from which it should never have emerged. Both Ryan and Colebatch, in reviewing the big biographies of Clark, encapsulated this ambivalence by trumpeting Clark's unlikeable qualities and then asking: why bother with him at all? ${ }^{32}$ Journalist Paul Kelly, in 2009, took the latter course and was utterly dismissive, declaring:

28 Roslyn Russell (ed.), Ever, Manning: Selected Letters of Manning Clark, 1938-1993, Sydney: Allen \& Unwin, 2008, p. 444 (Clark to Lyndall Ryan, 19 August 1984).

29 Peter Coleman, 'Fifty Years in the Front Line', Quadrant, vol. 50, no. 11, November 2006, pp. 26-27.

30 Mark McKenna, 'Being There: The Strange History of Manning Clark', The Monthly, no. 21, March 2007, pp. 22-37.

31 For example, David Marr, 'The man who wasn't there: Manning Clark's fraud exposed', Sydney Morning Herald, 5 March 2007, p. 1; 'Clark's biographer speaks about historian's past' (Mark Colvin interviewing Mark McKenna), 5 March 2007, available at: www.abc.net.au/reslib/200703/ r129612_427103.mp3 (audio); www.abc.net.au/pm/content/2007/s1863641.htm (typescript).

32 Peter Ryan, 'Hollow Man of Yesterday', review of Manning Clark: A Life, by Brian Matthews, Quadrant, vol. 53, nos 1-2, January-February 2009, pp. 126-28; Hal G.P. Colebatch, 'Sins of omission', review of An Eye for Eternity, by Mark McKenna, Spectator Australia, 25 June 2011, available on 17 June 2013 at: www.spectator.co.uk/australia/7049633/australian-books-sins-ofomission/ (no longer available on the publisher's website). 
Lawson and Clark said Australians had to choose between the old dead tree and the young tree green. But the Australian people, wisely, decided this was a false choice. They repudiated Clark and Lawson. ${ }^{33}$

John Howard also seems to have got the message. During his prime ministership he frequently criticised Clark for disparaging the Australian achievement but reduced the object of his previous ire to a solitary passing mention in his autobiography_on a matter that had nothing to do with the History Wars. ${ }^{34}$

In any case, Clark's public profile had long been on the wane, despite the continued white-anting in Quadrant. As a public intellectual, he was a man of the moment. By the turn of the century, he had passed his use-by date. Clark's biographer McKenna acknowledged in 2011 that Clark would, by then, be 'laughed out of court', but in the 1970s and 80s

Australians wanted someone, or needed someone, to talk, or point to [their] identity, their future-who were we as a people?[whereas today we are] standing solidly behind a more conservative and less critical view of ourselves. ${ }^{35}$

So, Clark is no longer the public presence that he once was, especially as the History Wars have taken different turns. In what might be a temporary respite, the History Wars no longer held centre stage in national life as in the early to mid-2000s when the print media would likely be reporting that yet another front had opened up. ${ }^{36}$ As Frank Bongiorno remarks:

There's continuing interest in Clark, but inevitably, the caravan's moved on somewhat. I'm more than ever struck by his importance as a cultural icon of post-imperial Australia - that is, the world of the mid-to-late 1960s, 1970s and climaxing in the Bicentenary of 1988. As soon as the post-imperial moment turned into the mixture of globalisation and cultural warfare that we've had since the mid-1990s, Clark was of little use to either the left or right. Perhaps the Ryan affair was [a late] gasp of the old order. ${ }^{37}$

33 Paul Kelly, The March of Patriots: The Struggle for Modern Australia, Melbourne: MUP, 2009, p. 71.

34 John Howard, Lazarus Rising: A Personal and Political Biography, Sydney: Allen \& Unwin, 2010, p. 73.

35 'Making History: Mark McKenna on Manning Clark' (interviewed by Michael Cathcart), Wheeler Centre, Melbourne, 6 June 2011 (starting at 11.20 minutes), available at: www.wheelercentre. com/broadcasts/making-history-mark-mckenna-on-manning-clark/.

36 Luke Trainor, review of The History Wars, by Macintyre and Clark, New Zealand Journal of History, vol. 38, no. 2, 2004, pp. 308-9 , specifically p. 308, available at: www.nzjh.auckland.ac.nz/ docs/2004/NZJH_38_2_14.pdf.

37 Frank Bongiorno, email to author, 9 May 2018. 
Clark's reputation as an historian is also in decline, which would have horrified him. Michael Cathcart has put it with eloquence in suggesting:

Manning lived in a state of existential agitation-that he feared that a great nothingness lay beyond death and that he was terrified by the loneliness of that prospect. It was appalling to him that life-especially his life-should end in nullity ... At a deep level, I think that Manning was in search of immortality ... A History of Australia is his attempt to write his life onto the great wilderness of Australia so that its very history becomes his mausoleum. ${ }^{38}$

Yet his eclipse is hardly a cause for surprise considering that historians typically have short shelf lives, even those who were well known and widely read during their lifetimes. When G.M Trevelyan's biographer presented a paper on Trevelyan (1876-1962) at the University of Cambridge in the late 1980s 'the majority of graduate students [in the audience] admitted to never having read him', or even heard of him, despite Trevelyan's prolific published output, his public profile and his long association with Cambridge. ${ }^{39}$ This was less than 30 years after Trevelyan's death. In similar fashion, almost all members of an honours class in Australian historiography at the University of Melbourne in 2018 had no prior knowledge of Clark. ${ }^{40}$ The paradox is that, despite his diminished reputation and his probably being little read by the general public anymore, Clark retains a cultural presence and continues to be discussed in the context of academic discourse. It is more than a cottage industry. Ironically, Clark ignored the profession in the History, but the profession is by no means ignoring his cultural influence, and this despite his fading professional and historiographical reputation. He remains by far the most discussed of all Australian historians (Appendix 4). Events thus far have confirmed Stuart Macintyre's 1994 prediction that Clark's position as a writer and influential figure in Australian cultural life is assured'. ${ }^{41}$

38 Michael Cathcart, email to author, 20 October 2017

39 David Cannadine, G.M. Trevelyan: A Life in History, London: Fontana Press, 1993, p. xii.

40 Stuart Macintyre, comment on earlier version of this book, 3 April 2018.

41 Stuart Macintyre, "'Always a pace or two apart"', in Carl Bridge (ed.), Manning Clark: Essays on his Place in History, Melbourne: MUP, 1994, pp. 17-29 (text), pp. 212-13 (endnotes), specifically p. 29; see also John Reeve, 'Masters of History: Three Students of Trinity College', Victorian Historical Journal, vol. 80, no. 1, 2009, pp. 76-90. 
Clark's continuing cultural profile confounds Ryan's 1993 pronouncement about 'the imminent and inevitable crumbling of Clark'. ${ }^{42}$ As if to make a wish come true, Ryan repeatedly white-anted his former author. In 1994 he noted that Clark was missing from a line-up of 30 prominent Australians in an issue of the Australian commemorating its first 30 years-proof in Ryan's eyes of the early eclipse of Manning Clark. ${ }^{43}$ And in 2005 Ryan wrote:

it is now more than 10 years since Australia's historical charlatanin-chief, Manning Clark, was toppled from his pedestal ... It is today most unusual to hear Clark quoted as an historical authority on anything at all. ${ }^{44}$

The latter point is true enough, but in what ways are Manning Clark's History likely to have an afterlife? My own prediction is that what is now a secondary source will probably become a primary source in future contexts. Ryan had his own view about this from the vantage point of 1993:

What, then, has preserved the existence, and even the influence, of this immense and odd cultural artefact? Perhaps it survives as a relic, a product of the sixties and seventies which an aging generation still clutches as a security blanket? Perhaps, deep in many an unconscious, it retains vague but comforting associations with Woodstock and Vietnam protests and nice Mr Whitlam who, on the very point of establishing the kingdom of heaven upon earth, was 'crucified' by the 'forces of Mammon' [as Clark put it]? Perhaps ... who knows. ${ }^{45}$

Along with Macintyre, I would venture to suggest that, far from being an ephemeral relic, Clark's History will continue as an important cultural artefact. Perhaps historian James Griffin was a little too grudging when predicting in 1995 that the History will stand on the shelves as a curiosity of historically based literature and nationalist polemics. ${ }^{46}$ Like Edward Gibbon and Thomas Babington Macaulay before him, Clark's History of Australia will retain value, for all its idiosyncrasies, as an indicator

42 Peter Ryan, 'A Reply to my Critics', p. 222.

43 Peter Ryan, 'The Charge of the Lightweight Brigade', in his Lines of Fire, pp. 222-34, specifically p. 223; see also the Australian, 16 June 1994, p. 1 (Special Commemorative Edition).

44 Peter Ryan, 'Apologise to Blainey', Australian, 15 December 2005, p. 10.

45 Ryan, 'Manning Clark', pp. 213-14.

46 James Griffin, 'The historiographer Clark unravelled', review of Manning Clark, ed. Carl Bridge, Australian, 1 February 1995, p. 26. 
of a selection of political and social assumptions at its time of writing, and the extent to which underlying assumptions shifted with successive volumes. In those respects, the History will live on whereas the more academically respectable monographs from the period will bite the dust and join the great unread, if they have not done so already. Paul Bourke added a further dimension when the controversy erupted:

Clark's [History] was a special kind of historical enterprise, much like the work of the 19th century American writer George Bancroft or the English G.M. Trevelyan. These authors who wrote multivolume histories of their countries, have not been read for their access to an uncontroversial body of fact; these writers have had the function of assisting a wide range of people in their societies to think about their origins, their identities and their common life. Historians rarely have such audiences. ${ }^{47}$

Whether Clark's History, with its repetitive clichés and overwrought prose, will be read as literature, in the manner that Gibbon and Macaulay are to this day, is a moot point. The exception might be his set piece narratives where story-telling ability really matters. Otherwise, in the words of Norman Etherington, 'the current scholarly consensus [is] that [Clark] did not come within cooee of greatness as a writer of history'. ${ }^{48}$

And what of Peter Ryan? Predictions are hazardous but the attempt must be made here too. As already mentioned, Bruce Anderson said in 1995:

[Ryan] claims, 'You never hear Manning Clark mentioned today'. Whether that is the case or not, one thing is certain, Peter Ryan would not be mentioned if it were not for Manning Clark. ${ }^{49}$

That is to overstate one's case, but not by much. Frank Bongiorno suggests that 'Ryan really had two great stories in him. He'd offered one many decades before, in his war memoir. The other was his relationship with the country's most famous historian'. ${ }^{50}$ To be sure, Ryan was largely identified as the publisher of Clark's History, a twinning that he clearly

47 Paul Bourke, 'Ryan is playing with the "pornography of power"', Canberra Times, 28 August 1993, p. 4.

48 Norman Etherington, 'The Spectre of Manning Clark', review of An Eye for Eternity, by Mark McKenna, Australian Book Review, vol. 337, December-January 2011-12, pp. 12-14, specifically p. 12. 49 Anderson to the Editor, Australian (undated; not published), attached to Anderson to Dymphna Clark, 18 August 1995, Dymphna Clark Papers, NLA), MS 9873, Series 10, Box 35, Folder 3. Anderson was responding to what Ryan was quoted as saying in an untitled article in the Weekend Australian Magazine, 29 July 1995, p. 17.

50 Frank Bongiorno, email to author, 4 April 2018. 
disliked despite persisting in being its publisher. But with Clark gone, Ryan developed a literary life of his own with, successively, his Age and Quadrant columns. Whether his legacy will rival Clark's is improbable: this book (and John Tidey's Ryan's Luck) may prolong his afterlife, but his supporters are old and few and he will largely fade away. Ask current readers of the Age who Peter Ryan is, and they will more likely identify his namesake, who joined the newspaper in 2017 as a senior sports reporter-a sublime irony given that our Peter Ryan so detested team sports. Ryan's Nation, Age and Quadrant columns, taken in their entirety, may coalesce into a cultural artefact and might even capture the attention of a postgraduate student in search of a thesis topic-in other words to become fodder for the 'thesis mills' he so despised.

Ryan might have made an early contribution to the ongoing Clark industry had he availed himself of an unexpected opportunity. In response to his first attack in Quadrant, the English publishing house of Andre Deutsch enquired whether he would be interested in writing a biography of Clark. Although gratified by the offer, Ryan declined, explaining that his postretirement job as clerk of the Supreme Court of Victoria left him with limited opportunity for his own writing 'in the short time left to me'. ${ }^{51}$ It was a wise decision from all points of view. Ryan would not have been able to spend the necessary time in Canberra consulting the papers of Manning Clark. Even had he done so, his three Quadrant articles suggest that any such biography would have been an extended and intellectually uninformed diatribe. As Peter Craven remarked, Ryan's depiction of his relationship with Clark in his first Quadrant essay

reads like a portrait of Hamlet as an old goat written by an aging Horatio who seems to have spent half his time wishing he could run through the crazy bastard with his sword ... There is a sense in which the face which stares back at us from Ryan's essay, by virtue of the power of his writing and his willingness to persevere with his own contradictions, is the face of Manning Clark (transfigured as he could never have done deliberately himself in his writings) into a comic character. ${ }^{52}$

51 T.G. Rosenthal to Ryan, 19 October 1993, and subsequent correspondence, in Ryan Papers, NLA, MS 9897, Series 6, Box 10, Folder 4. Ryan suggested the journalist and writer Michael Duffy as an alternative, but the latter 'didn't think he would have time, so he declined with very great regret'. 52 Peter Craven, 'The Ryan Affair', in Bridge, Manning Clark, pp. 165-87 (text), p. 224 (endnotes), specifically p. 175 . 
Ryan's life of Clark, had he written it, might have bolstered his reputation as a 'master of anecdote and caricature' but the eventual book would not have remotely approached the standard of Stephen Holt's short biography of Clark, published in 1999. ${ }^{53}$

Despite the difficulties he experienced as Clark's publisher, I believe that Ryan behaved badly and was culpable in his many misrepresentations of events; he emerges from the episode with little credibility. That said, I am not faulting Ryan for expressing disapproval of Manning Clark per se. Nor am I sure that I subscribe to the view that a publisher has a confidential relationship with an author; if so, then historians breach this confidentiality every time they discuss publisher-author interactions, as I have in this book. One might also argue that if Ryan praises those whom he considers virtuous authors, then he is entitled to express dissatisfaction with the miscreants, as he does in his autobiography. ${ }^{54} \mathrm{But}$ if the publisher-author relationship is seen as one of mutual trust and support, then Ryan clearly transgressed. Louise Adler, then director of Melbourne University Press (hereafter MUP), entertained no doubts on the matter and made her views abundantly clear at the launch of An Eye for Eternity in 2011. Reminding the audience that 'Manning Clark and MUP ... had a complex history', she went on to say:

MUP profited immeasurably from publishing his six-volume History of Australia. Some might say that the Press's Director during that time made his own reputation as a consequence, on the back of Manning Clark ... no one here today will be unaware that that same publisher would, much later on, make his own highly pejorative views of his author known. My own personal view is that the publisher's first loyalty is to one's author. We publishers can actually choose to take on a book or not, we can share the author's views or not, but we actually in the end owe both the book and the author enduring loyalty and advocacy of their work. ${ }^{55}$

53 Peter Craven, 'Veil of death draws to a close several artistic eras', Australian, 18 January 1995, for quotation see p. 28; Stephen Holt, A Short History of Manning Clark, Sydney: Allen \& Unwin, 1999.

54 Peter Ryan, Final Proof: Memoirs of a Publisher, Sydney: Quadrant Books, 2010, pp. 170, 180-82.

55 Louise Adler, at the launch of An Eye for Eternity, Sydney, 19 May 2011, starting at 2.36 minutes, available on 28 November 2011 at: www.mup.com.au/page/92 (no longer available on the MUP website). 
Directly after his first attack on Clark, a newspaper correspondent asserted:

Peter Ryan must, through his academic experience over 26 years as the supremo at Melbourne University Press, and his intimate knowledge of the man and of the massive six-volume work, be accepted as an 'expert witness'. .5

Ryan was an unreliable witness, and in ways that undermine his version of events: 'frivolous and vexatious' might be a better legal expression to describe Ryan's testimony. What he says about Clark as a person, although largely correct, fails to capture his complexity. It is also irrelevant and should have been 'struck off the record'. His criticisms of the History are wholly unoriginal. To continue with legal jargon, Ryan perjures himself by saying that he inherited an open-ended contract, and he creates a quite false impression by not revealing that he resisted all opportunities to terminate Clark's project, or else to shuffle it on to another publisher. His assertion that Clark was shielded by a duplicitous historical profession does not stand up to scrutiny. He suppressed information that discredits his argument, and his denial that he was politically motivated is an outright falsehood.

But why are there so many mistakes and distortions? One reason might be that Ryan was writing largely from memory, and another that Ryan was loath to admit that he might have been wrong or mistaken. Having burned his bridges with MUP, he no longer had access to his former employer's records. He still had his own papers (which were purchased by the National Library of Australia in 2003) but these contain little material concerning the publication of the History. To compound the problem, once Ryan got something in his head, it was entrenched and assumed the status of truth personified. I was alerted to this when reading his statement that A.E. Housman's A Shropshire Lad was an instant commercial success, which I knew was not the case at all. ${ }^{57}$ What happened was that Ryan misunderstood the relevant passages in Richard Perceval Graves's biography of Housman and the mistake carried through over time; over 30 years later he repeats

56 Bob Morrow, 'Emperor's new clothes' (letter), Daily Mail (Sydney), 2 September 1993, p. 8; see also 'Editorial: 'Manning Clark’s blinkered view', Courier-Mail, 31 May 1997, p. 22.

57 Peter Ryan, 'A Shropshire Lad of Genius' (1988), in Ryan, Lines of Fire, pp. 48-51, specifically p. 49; see also A.E. Housman, The Works of A.E. Housman, Hertfordshire: Wordsworth Poetry Society, n.d., p. ix; Norman Marlow, A.E. Housman: Scholar and Poet, London: Routledge \& Kegan Paul, 1958, p. 9; Richard Perceval Graves, A.E. Housman: The Scholar-Poet, London: Routledge \& Kegan Paul, 1979, pp. 111, 113, specifically p. 119. 
the initial misapprehension in his autobiography. ${ }^{58}$ It is a common enough phenomenon, as evidenced by historian Lewis Namier (1880-1960) whose frequent retellings of his reminiscences elevated their inaccuracies to gospel truth in his own mind. ${ }^{59}$ On another occasion Ryan claimed that a series that MUP intended publishing on Asian contract law was terminated after the first volume, on the grounds that the series was receiving the financial backing of the CIA (as had Quadrant in its earlier years). One of the series editors offered the correction that CIA funding had long ceased, but Ryan persists with his mistaken version in his autobiography. ${ }^{60}$

Being captive to the idée fixe may also explain why he continued to believe that he inherited an unsatisfactory contract with regard to Clark's History; and why he was so reluctant to back down from the idea that academic reviewers gave the History a free ride. It may also explain why Ryan kept insisting that The Musical 'was a ghastly flop, rushed red-faced off the stage after a run of a few days', a point he reiterates in 1999 when disputing Stephen Holt's more accurate assertion that it limped on for 'some six weeks' (mid-January to late February 1988). ${ }^{61}$ Ryan repeats his own mistakes even when offering correction to others.

Another feature is Ryan's lack of self-perception. In the light of the false representations, strategic omissions and outright errors of fact in his three Quadrant articles, it is oddly out of place that he approvingly paraphrases Eric Hobsbawm's argument:

That facts exist, and are the starting point of history; that the truth can be found and is not merely the plaything of subjectivist intellectuals; that historians must not bend facts and history for

58 Ryan, Final Proof, pp. 178-79.

59 D.W. Hayton, Conservative Revolutionary: The Lives of Lewis Namier, Manchester: Manchester University Press, 2019, p. 5.

60 Peter Ryan, 'Throw the book' (letter), Australian, 26 January 1999, p. 12; David E. Allen, 'Clear funds for new book', Australian (letter), 4 February 1999, p. 12; Ryan, Final Proof, p. 166. Quadrant was just one of a number of journals worldwide that, knowingly or unknowingly, received CIA money through front organisations. John Leonard, 'It's not the gift, it's the thought behind it', New York Times, 8 October 1972, p. BR47, available at: www.nytimes.com/1972/10/08/archives/ its-not-the-gift-its-the-thought-behind-it.html.

61 Peter Ryan, 'Folk Memory v History', Quadrant, vol. 43, no. 10, October 1999, pp. 70-71, specifically p. 70; Ryan, 'Manning Clark's second coming', Australian, 10 February 2007, for quotation see p. 29 'Manning Clark', pp. 203-4; Peter Fitzpatrick, "'History-The Musical": A Review and a Retrospect', Australian Historical Studies, vol. 23, no. 91, 1988, pp. 171-79, specifically p. 171, doi.org/10.1080/10314618808595802; Holt, A Short History of Manning Clark, p. 220; John Bell, The Time of My Life, Sydney: Allen \& Unwin, 2002, pp. 157-81; Sophie Cunningham, Melbourne, Sydney: NewSouth, 2011, p. 96. 
ideological purposes; and that historians must stand aloof from the passions of national identity politics. For me, a canon of historiographical integrity is established on such principles, and Manning Clark sinned against every one of them. ${ }^{62}$

Peter Ryan also sinned against every 'canon of historiographic integrity' if it comes to that. His wont of self-perception is also illustrated by his reaction to 'a personal account' he was commissioned to write for Australians: A Historical Library (1987) being rejected. What started as a moving description of Depression-time Australia degenerates into a tirade about the woeful state of the nation and the idiot politicians trying to run the show. It is amazing that Ryan, himself an academic publisher, could never see why it had to be rejected out of hand-not on grounds of political correctness as he claimed but because a rant of that nature had no place in a scholarly collection. ${ }^{63}$

Yet Ryan called for 'a little honest introspection by Australian historians' ${ }^{64}$ and goes on to say that history in Australia 'has been "professionalised", if not out of existence, then beyond relevance to ordinary people'. ${ }^{65}$ There is no recognition that he takes a share of the responsibility given that MUP published many such books under his watch, and he overlooks the fact that his decision to bring out paperback editions of the History 'was instrumental in steering Clark's work towards an even more popular audience'. ${ }^{66}$ It escapes him entirely that the work he particularly regrets having published subverted the insidious professionalisation of the historical discipline, since it was written for a general readership and was snapped up by its tens of thousands by 'ordinary people'. Ryan also derides Clark's 'passion to be a public figure', ${ }^{67}$ despite his own ambitions in that direction and the fact that Clark's public profile increasingly enhanced the sales of the History. And, to repeat, neither does he explain why he never confronted Clark with his concerns, despite promptings from his critics, including an early (and unanswered) enquiry from a correspondent on that very point:

62 Ryan, 'The Charge of the Lightweight Brigade' p. 233; see also Eric Hobsbawm, 'Fact, fiction and historical revisionism', Australian, 8 December 1993, p. 21.

63 Peter Ryan, 'End of the Dreamtime' (1986), in his Lines of Fire, pp. 101-11. Ryan's biographer is equally uncomprehending as to why the essay was unpublishable in an academic outlet. John Tidey, Ryan's Luck: A Life of Peter Ryan MM, Melbourne: Arcadia, 2020, pp. 92-93.

64 Ryan, 'A Reply to my Critics', p. 221.

65 Ryan, 'The Charge of the Lightweight Brigade', p. 232.

66 McKenna, An Eye for Eternity, p. 588.

67 Ryan, 'Manning Clark', p. 202. 
As I read [your 28 August article in the Australian], one question came to my mind and I anxiously read on expecting an answer. It was not there. To satisfy my curiosity I must ask- 'why did you not express these criticisms while Clark was alive?'. Was it your friendship? ${ }^{28}$

There was ample opportunity to raise such matters with Clark, but Ryan had long given up discussing 'editorial problems' with Clark, even via their correspondence. He should not then lay the blame on Clark for the lack of frank discussion between author and publisher.

There are also the false claims. In a 2007 article in the Australian, Ryan maintained that 'My Quadrant essays (September and October 1993, October 1994) cover the whole of Clark's career and all his published books' ${ }^{69}$ In fact, Clark's two volumes of Select Documents in Australian History (1950, 1955), his Meeting Soviet Man (1960) and A Short History of Australia (1963) are only mentioned in passing, while Sources of Australian History (1957) and In Search of Henry Lawson (1978) are not mentioned at all. And the three Quadrant articles, even in their entirety, add up to a very patchy and lopsided account of Clark's career. One has to ask how far Ryan's version enhances our understanding of Clark and his work, and the temptation is to apply A.G.L. Shaw's assessment of Volume 1, that 'the inaccuracies taken together are irritating, and add up to create a sense of mistrust in the work as a whole'. ${ }^{70}$

Some of these errors and misconceptions can be put down to the honest mistakes that we all make from time to time, but their frequency suggests Ryan was unconcerned about whether he was right or wrong so long as he was persuasive and beguiling. The most charitable interpretation is that he did not take reasonable steps to ensure the accuracy of his information. He did not seem to care whether he was caught out-he would ignore or else deny the charge and go on the counterattack. In a word, he was dissembling. Instead of writing to further 'the survival of historical truth, ${ }^{71}$ his attacks on Clark were malicious and politically motivated,

68 Cyril White to Ryan, 21 September 1993, Ryan Papers, NLA, MS 9897, Series 6, Box 10, Folder 2. Ryan claimed to have received many abusive letters in the wake of his September 1993 Quadrant article. None of these is in his papers so presumably he threw them away in disgust. Cyril White's is the only letter in the Ryan Papers containing criticism.

69 Peter Ryan, 'Manning Clark's second coming', Australian, 10 February 2007, p. 29.

70 A.G.L. Shaw, 'Clark's History of Australia', Meanjin Quarterly, vol. 22, no. 1, 1963, pp. 117-19, specifically p. 119.

71 Ryan, 'A Reply to my Critics', p. 225. 
enabling Ryan to get back at Clark and in the same breath to perpetuate his own public profile. He was simply not interested in telling the truth any more than he was in checking his facts and avoiding distortions. When accused of being ungrateful for the Clarks' hospitality, for example, his response was that it amounted to 'one scratch lunch to me and my friend Gerry Gutman' - a slanderous statement given Dymphna and Manning's renowned hospitality, whether at their Canberra home or their beach house at Wapengo on the southern New South Wales coast. ${ }^{72}$

The broadsides on Clark were in keeping with the common tactic during the History Wars of impugning the character of a target. But until then there had not been such a sustained attack on an individual, apart from the hue and cry surrounding Geoffrey Blainey's criticisms of immigration policy and, by implication, multiculturalism-and even then Blainey stoked the flames rather than allowing the controversy to subside. ${ }^{73}$ As well, Ryan was also the first to inject such a personal element. It was a full-scale assault citing personal and professional dealings. Linked to it was a splenetic but unoriginal denunciation of the History. He purported to set the record straight but instead engaged in wide-ranging dishonesty, especially in denying that he was politically motivated. His contribution also involved systematic misrepresentation and vilification. Ryan himself asked:

Is it a disreputable national trait of us Australians to mangle and distort the characters of the dead? To twist them recklessly in any way which current ideology or particular literary purpose needs? My own answer is Yes. ${ }^{74}$

\footnotetext{
72 Peter Ryan, 'Fighting words', review of The History Wars, by Macintyre and Clark, Australian, 6-7 September 2003, p. R11. The hospitality of the Clarks is ubiquitously documented: Nicholas Gruen, 'On Reading Mark McKenna's Biography of Manning Clark', 25 August 2011, available at: staging.insidestory.org.au/on-reading-mark-mckennas-biography-of-manning-clark/; Bob Reece, "'Don't accept any lifts from professors to Wagga": Some Personal Recollections of Manning Clark', Australian Historical Association Bulletin, vol. 83, 1996, pp. 86-92, specifically p. 89; Katerina and Axel Clark, interviewed by Susan Marsden, 19 June 2001, NLA, ORAL TRC 4770 (p. 47 of transcript); Roslyn Russell, email to author, 25 May 2020; McKenna, An Eye for Eternity, pp. 269, 312, 508, 544.

73 H.W. Dick, 'The Immigration Debate Revisited', Asian Studies Review, vol. 9, no. 2, 1985, pp. 150-56, doi.org/10.1080/03147538508712398; Richard Allsop, Geoffrey Blainey: Writer, Historian, Controversialist, Melbourne: Monash University Press, 2019, pp. 142-43, 160; Eric Richards, Destination Australia: Migration to Australia since 1901, Sydney: UNSW Press, 2008, pp. 284-88; Frank Bongiorno, The Eighties: The Decade that Transformed Australia, Melbourne: Black Inc., 2015, p. 64; Macintyre and Clark, The History Wars, p. 82.

74 Peter Ryan, 'Problems with the Truth', Quadrant, vol. 48, no. 9, September 2004, pp. 95-96, specifically p. 95.
} 
Such a claim is borne out by his treatment of Clark. The fraudulence that he saw in the History and the dishonesty that he detected in Clark repose in himself. ${ }^{75}$

Ryan was a contradictory and perplexing individual in whom the elements were strangely mixed. Energetic and resourceful, he was a fine writer who wasted his talents on invective, both in word and in print. He deplored Paul Keating's studied insults, ${ }^{76}$ but he more than matched Keating in that department. He was intensely loyal to friends and hateful towards those who aroused his ire. Indeed, one might wonder how Ryan, who claimed to have had an 'amazingly happy life, ${ }^{77}$ could have been so combative and embittered. An arch empiricist and a stickler for accuracy in others, he was indifferent to the truth when it came to himself. He berates Clark for his 'unreliability with mere facts', but his own writings are replete with errors and misrepresentations. His deceit and deception point to something else-namely, the element of the hypocrite, starting with his insincere flattery of Clark. He was also two-faced. As a publisher, Ryan inveighed against Literature Board grants and other forms of subsidising authors, ${ }^{78}$ while happily taking advantage of the book bounty, the indirect subsidy provided by his monopoly of campus book sales, and MUP's tax-free status as a result of being part of the University of Melbourne. $\mathrm{He}$ did at least acknowledge the latter. ${ }^{79}$ Neither did Ryan object to MUP publications being subsidised, whether from private monies or the public purse (the CSIRO subsidised The Insects of Australia).$^{80}$ As Stuart Macintyre remarked, 'Peter Ryan has been very good at having his cake and eating it too'. ${ }^{81}$ How much of this can be attributed to emotional damage during the war is unknown, but probably that had a bearing on his approach to life and affairs.

75 Ryan, 'Manning Clark', pp. 200-1 and 'The Charge of the Lightweight Brigade', pp. 228-29.

76 Tidey, Peter Ryan, pp. 102-3.

77 Ryan, 'End of the Dreamtime', p. 111.

78 Peter Ryan, 'A Shropshire Lad of Genius' (1988), and 'A.D. Hope: A Memoir' (1992), in his Lines of Fire, pp. 50, 153-76, 167 respectively; Ryan, 'Writer's spat over the public purse', Age, 13 February 1993, p. Extra 2 ('As I please' column); Ryan, 'Ingrate Writers of Our Times', Quadrant, vol. 44, no. 4, April 2000, pp. 87-88; Stuart Glover, 'Literature and the State', in Robyn Sheahan-Bright and Craig Munro (eds), Paper Empires: A History of the Book in Australia, 1946-2005, Brisbane: University of Queensland Press, 2006, pp. 165-73, specifically p. 168.

79 Ryan, Final Proof, p. 121.

80 Ryan, Final Proof, pp. 101, 107-8.

81 Quoted in Louise Carbines, 'Publisher pays out on Manning Clark's "fairy floss"', Age, 26 August 1993, p. 1. 
Let Ryan have the last word in a summation of Clark that is a mirror image of himself: 'Why did he behave so? He was a wilful sinner, in my opinion; he knew he was doing wrong, and he went on doing it, and profiting from it'. ${ }^{82}$

But not quite the last word. Clark's adversary Colin Roderick recognised from the outset that the controversy

is likely now to turn into a political dogfight-left v. right. Unhappily almost all social questions in Australia today seem to have descended to this, so seriously are we 'polarized' ${ }^{83}$

The irony is that Roderick was actively in touch with Ryan and egging him on, but his instinct about the course of the controversy was correct. Indeed, a feature of History Wars is that what starts as a noisy debate, ostensibly about issues, quickly degenerates into personal abuse and finger-pointing, as Anna Clark discovered. Her discussion of the history curriculum for school children as an aspect of the History Wars drew some disconcerting attacks on the spurious grounds that she was Manning Clark's granddaughter and therefore had a conflict of interest when in fact she has always avoided coat tailing on the reputation of the grandfather she loved as a child. Questioning the integrity, credibility and competence of participants becomes the order of the day. It usually continues to the point of no return as the belligerents paint themselves into a corner in the fashion of Ryan's first Quadrant article, which had no hope of creating genuine dialogue given the atmosphere of the early 1990s. What it did do was to turn up the heat, resulting in complaints from both sides that national debate was being reduced to 'an endless stream of invective'. ${ }^{84}$

Many of the Australian History War campaigns were just so much wasted effort. That is to say, a willingness to acknowledge past injustice is not inconsistent with recognising Australia's British heritage. Multiculturism, furthermore, doesn't spell the doom of European civilisation. Clark personified the latter point in that he was ahead of his time in the 1950s in recognising the importance of Asia to Australia and yet his traditions

82 Ryan to J.P. Parsons, 16 December 1993, Ryan Papers, NLA, MS 9897, Series 6, Box 10, Folder 5.

83 Roderick to Ryan, 28 August 1993, Ryan Papers, NLA, MS 9897, Series 6, Box 10, Box 4.

84 'Debunking a national icon', News Weekly, 11 Sept 1993, for quotation see p. 7; Peter Corrigan, 'Brave new worlds', Age, 16 October 1993 (by-line column), p. 11. 
were those of Europe-its music, its institutions and its literature. Clark never really fitted into the caricature developed of him by Howard and others on the conservative side of politics. In any case, adherence to either the black-armband school or the three-cheers school is often not about history at all but a function of individual circumstance. An émigré from Nazi Germany who has gone on to prosper is more likely to view Australia as a land of opportunity - a positive view that would hardly be shared by the long-term unemployed. ${ }^{85}$

But that does not prevent public debate becoming polarised around adversarial binaries, which minimises the space for constructive commentary. In this way, History Wars revolve around destructive dichotomies, where the original objective or point of contention tends to get lost. Or else those involved are talking past each other, as Anna Clark noted when Henry Reynolds and Keith Windschuttle attempted, in 2000, to debate historians' accounts of the frontier wars. She found it 'excruciating':

The two speakers couldn't engage with one another on any level. Their arguments snapped and slashed with brittle vehemence as they stood on a balcony above the audience, and they became increasingly frustrated and irate. ${ }^{86}$

The Climate Wars are another example of a no-holds-barred situation. ${ }^{87}$

Confrontational opposition is not the way to come to terms with the past, nor a means of resolving valid differences. As McKenna says, 'The time for pitting white against black, shame against pride, and one people's history against another's has had its day'-a sound principle but not one that is amenable to being put into practice. ${ }^{88}$ Rather, damaging, unproductive and pointless confrontations are forever afoot. Yet the message should be heeded that 'a country that has the courage to look its history in the eye will be the stronger for it'. ${ }^{89}$

85 Eugene Kamenka, “'Australia Made Me” ... But which Australia is Mine?', Quadrant, vol. 37, no. 10, October 1993, pp. 24-31.

86 Anna Clark, 'The History Wars', pp. 151-52.

87 Peter Doherty, The Knowledge Wars, Melbourne: MUP, 2015; Mark Butler, Climate Wars, Melbourne: MUP, 2017.

88 Mark McKenna, 'Moment of Truth: History and Australia's Future', Quarterly Essay, no. 69, January 2018, pp. 1-83, specifically p. 73. Comparable thoughts are expressed by David Cannadine, The Undivided Past: Humanity Beyond our Differences, New York: Alfred A. Knopf, 2013, doi.org/ 10.1515/ngs-2013-018.

89 McKenna, 'Moment of Truth', p. 71. 
These are counsels of perfection for the Australian History Wars, with their entrenched binaries, which are most likely here to stay and to be 'dominated by a public debate that's simplistic, divisive and overly partisan'..$^{90}$ They are often driven by the print media and in ways that encourage polarised thinking by setting up adversarial scenarios where neither side yields an inch. It is called 'balance'. The media are also in a position to set the terms of a given History War by what they choose to publish or not to publish, and by what they commission and the columnists they hire. More pointedly, journalist Laura Tingle has observed that 'the culture wars ... are the stock-in-trade of Rupert Murdoch's media empire'. ${ }^{11}$ Social media now chimes to the accompaniment of the mainstream, its immediate and often unrestrained rejoinders discordantly raising the temperature. The study of history itself is the casualty. The other consideration is that nation states do not want their indiscretions publicised or their past blackened and will often resort to prescriptive interventions, the Armenian genocide being a prime example. While there is nothing wrong with historical perspectives being utilised to inform policy decisions, ${ }^{92}$ it is singularly unhelpful when politicians hijack history, or promulgate a view of the past, to bolster their own agendas.

One such occasion was John Howard's memorable intervention, in 2004, involving a $\$ 31$ billion federal package for education spread over four years. There were numerous conditions, one of which was that individual schools would not receive any windfall unless they flew the Australian flag in the prescribed manner. There was no attempt to interfere with the history syllabus as such but the stipulation 'to fly the flag' was in response to Howard's (ostensible) perception that the 'value neutral' and 'politically correct' history being taught in state schools was causing an exodus of students to their private counterparts. (How 'value neutral' history can also be 'politically correct' history is indeed a teasing question.) It was all part of a broader campaign to foster patriotism and the teaching of 'proper' values in schools - in other words, his own version of what history ought to be. It raised a storm of censure with the federal president of the Australian Education Union saying that the measure was 'a preoccupation

90 Anna Clark, 'The History Wars', p. 152.

91 Laura Tingle, 'The High Road: What Can Australia Learn from New Zealand', Quarterly Essay, no. 80, December 2020, pp. 1-112, specifically p. 4.

92 For example, Julian M. Simpson, Kath Checkland, Stephanie J. Snow, Jennifer Voorhees, Katy Rothwell and Aneez Esmail, 'Adding the Past to the Policy Mix: An Historical Approach to the Issue of Access to General Practice in England', Contemporary British History, vol. 32, no. 2, 2018, pp. 276-99, doi.org/10.1080/13619462.2017.1401474. 
with appearances rather than substance. Issues of civics education are far more subtle, and far more wide-ranging than whether or not you have a functioning flagpole' ${ }^{93}$ By contrast, New Zealand's Prime Minister Jacinda Ardern wisely kept the question at arms-length when asked about a petition in 2019 from the New Zealand History Teachers' Association that the 'coherent' teaching of history be mandatory for all schools. She said that this was 'common sense' and left it at that. ${ }^{94}$ When a comprehensive new history syllabus for schools came out two-and-a-half years later, Ardern continued to deflect controversy by announcing the teachers would get the support they needed to implement such sweeping changes. ${ }^{95}$ It was not a matter of stifling debate but of avoiding unnecessary conflict and polarisation, and that is the way it should be, with politicians smoothing the way rather than stirring up discord. Neither should politicians attempt to impose prescriptive discourses of patriotism, wartime heroism and national greatness (or guilt for that matter) on educationalists. It is well said that 'professional historians and responsible teachers cannot "devote themselves to writing a catechism for someone's version of civil religion" and call the result history. ${ }^{96}$

In his attack on Clark, Ryan did allude to the History Wars in classrooms when he claimed that his criticisms of Clark were 'for the protection of the young and innocent'. ${ }^{77}$ The History, he claimed, 'might be dangerous to the mental health of young persons' ${ }^{98}$ These were quite spurious concerns. Instead, Ryan was motivated partly by the quest for notoriety; partly to get back at Clark for being a difficult author and a poseur to boot; partly to attack the History and to absolve himself from responsibility

93 Anna Clark, History's Children: History Wars in the Classroom, Sydney: NewSouth, 2008, pp. 51-53; Andra Jackson and Shane Green, 'Schools told to fly flag or lose cash', Age, 23 June 2004, for quotation, available at: www.theage.com.au/national/schools-told-to-fly-flag-or-lose-cash-20040623-gdy3ni.html. 94 Aaron Leaman, "Teaching New Zealand history "common sense": Prime Minister Jacinda Ardern', 13 June 2019, available at: www.stuff.co.nz/national/politics/113459160/teaching-newzealand-history-common-sense-prime-minister-jacinda-ardern.

95 'Teachers will get support they need to teach new history curriculum, PM says', Radio New Zealand, 7 February 2021, available at: www.rnz.co.nz/news/political/435954/teachers-will-get-support-theyneed-to-teach-new-history-curriculum-pm-says. New Zealand has not had a fully blown History War-yet. But see Vincent O’Malley and Joanna Kidman, 'Settler Colonial History, Commemoration and White Backlash: Remembering the New Zealand Wars', Settler Colonial Studies, vol. 8, no. 3, 2018, pp. 298-313, doi.org/10.1080/2201473X.2017.1279831.

96 Gary B. Nash, Charlotte Crabtree and Ross E. Dunn, History on Trial: Culture Wars and the Teaching of the Past, New York: Alfred A. Knopf, 1997, p. 227.

97 Ryan, 'The Charge of the Lightweight Brigade', p. 234.

98 Ryan, 'A Reply to my Critics', p. 214. 
for its propagation; partly to regain work as a columnist (this time for Quadrant); and partly to weigh in on behalf of the three-cheers school of history and thus ramp up the Australian History Wars.

Seen in this light, Peter Ryan was flying under false colours. He was not providing a much-needed exposé of a charlatan and his works. Rather, his attacks on Manning Clark in Quadrant were irresponsible and came from a self-interested polemic that debased national debate. His interventions had nothing to do with such mundane yet necessary matters as honesty, good faith and sound historical practice — and least of all with civic courage. 
This text is taken from History Wars: The Peter Ryan-Manning Clark Controversy, by Doug Munro, published 2021 by ANU Press, The Australian National University, Canberra, Australia.

doi.org/10.22459/HW.2021.09 